\title{
Research on the Influential Factors of Businesswomen's Physical Exercise under the Background of Universal Two-child Policy
}

\author{
Rui Meng ${ }^{1}$, Huanxiang Ding ${ }^{1}$ \\ ${ }^{1}$ College of Physical Education, Linyi University, Linyi City, Shandong Province, China
}

Keywords: universal two-child policy; businesswomen; physical exercise.

\begin{abstract}
With the methods of literature review, questionnaire and experts' interview, this paper analyzed the influential factors of the businesswomen's physical exercise under the background of universal two-child policy and summarized the main factors, which contributes to the improvement of the businesswomen's physical exercise and their physical quality.
\end{abstract}

\section{Introduction}

Since the universal two-child policy was issued, the one-child policy which lasted for 35 years has officially ended. This policy is beneficial to the women. Among the target 90 million people with two-child around the country, more than $50 \%$ of them are over 40 years old. The implementation of the universal two-child policy is a difficult choice for the businesswomen. Firstly, they are worried about their business after their birth. Secondly, they are worried about their age in maternal age and the risk of birth. Thirdly, they are afraid to take care of their first child and their education and life. Some businesswomen are also concerned about the care of the second child. For those who plan to have the second child and who has had the second child, the universal two-child policy has caused their physical and mental health. Women's health is related to the family and social harmony, reproductive health and the quality of family planning in the future. [1][2][3][4]

Businesswomen have been becoming increasingly prominent. Their contribution to the society is becoming increasingly significant. However, due to the restriction of their physiological and psychological characteristics, it is easier for them to cause different degrees of psychological problems. Scientific physical exercise is beneficial to regulate and promote their physical and mental health. 2016 is the first year of the 13th Five-Year plan, as well as the key year to promote the new development of maternal and neonatal health. The fifth Plenary Session of the 18th CPC Central Committee has issued the strategic decision of promoting the health construction in China. All these provide a historical opportunity for the development of maternal and neonatal health. Therefore, women's health is the demand of the times and it is urgent to promote women's health. [5][6][7][8]

\section{Research Participants and Research Methods}

Research participants. The research participants are 100 businesswomen who plan to have the second child and 100 businesswomen who have had the second child.

Research methods. Literature review. We explore into the concepts of health, physical exercise on the various domestic and foreign websites, as well as the businesswomen's characteristics, physical exercises, the national family planning policy, the selective two-child policy and the universal two-child policy, the influences of the universal two-child policy on the family and the female. [9][10][11][12][13]

Questionnaire survey. A. The questionnaire of the influential factors of businesswomen's physical exercise. B. The questionnaire of the businesswomen's willingness and the influential factors of the second child filled out by those who has only one child. C. The questionnaire of the businesswomen's health filled out by those who has had the second child.

The three types of questionnaires are designed based on principles. The validity and reliability of the questionnaires are tested. The questionnaires are simultaneously given out online and offline. The questionnaires are given out online through the network, WeChat, QQ and other platforms among the friends, the classmates, the teachers, etc. The questionnaires are given out offline in the current 
widely accepted first- tier, second-tier, third-tier and fourth-tier cities. Taken the geographical location and the economic foundation into consideration, three or four cities are selected as representatives in the sampling survey.

Experts' interview. The researchers visited the experts and scholars on medicine, psychology, demography, and sociology and so on to understand the relevant policies and factors affecting the physical and mental health of the businesswomen.

Mathematical statistics. The researchers used SPSS17.0 statistical software to collect data and make comprehensive, and in-depth data processing.

\section{Results and Analysis}

In the new social development of the universal two-child policy, this paper comprehensively analyzed the businesswomen's difficulties and pressures from the physical, psychological and social adaptation and other aspects to make the depth analysis of the influential factors of the businesswomen's physical exercise.

Hours spared in physical exercises of the businesswomen from different fields

Table 1 The businesswomen's time list in leisure sports

\begin{tabular}{|c|c|c|c|c|c|c|}
\hline Businesswomen & $\begin{array}{c}\text { Time } \\
\text { (hours/each } \\
\text { time) }\end{array}$ & $\begin{array}{l}\text { Salary } \\
\text { (ten } \\
\text { thousand) }\end{array}$ & $\begin{array}{c}\text { Consumption } \\
\text { (thousand/month) }\end{array}$ & $\begin{array}{l}\text { The } \\
\text { number } \\
\text { of the } \\
\text { people }\end{array}$ & $\begin{array}{c}\text { The } \\
\text { number of } \\
\text { the people } \\
\text { who plan to } \\
\text { have the } \\
\text { second } \\
\text { child }\end{array}$ & $\begin{array}{l}\text { Percentage } \\
\quad(\%)\end{array}$ \\
\hline $\begin{array}{c}\text { Enterprise } \\
\text { superintendents }\end{array}$ & $0.4-1$ & $1-2$ & $1-2$ & 40 & 6 & 15 \\
\hline Civil servants & $1-1.5$ & $0.3-0.6$ & $0.2-0.3$ & 40 & 32 & 80 \\
\hline Teachers & $1.5-2$ & $0.4-0.7$ & $0.3-0.4$ & 40 & 38 & 95 \\
\hline Doctors & 1 & $0.7-1.5$ & $0.5-1$ & 40 & 10 & 25 \\
\hline Workers & 0.5 & $0.2-0.4$ & 0.1 & 40 & 22 & 55 \\
\hline
\end{tabular}

Table 1 shows the time spent by different businesswomen in physical exercise. The person in charge of the enterprise and the workers spend less time in the sports leisure activities. The teachers, civil servants, doctors and other female groups relatively spend more time in physical exercise time. As can be seen from Table 1, the enterprise superintendents are responsible for the pressure due to their heavy work. They are busy and spend less time in the physical exercise. The hours spent in each exercise is mainly concentrated in 0.5 to $1 \mathrm{~h}$. Due to the pressure of work, the ordinary enterprise workers have a large number of daily consumption of physical strength in their work. Thus, there is no extra time and energy for them to put into physical exercise. Most of these people spend less than $0.5 \mathrm{~h}$ in physical exercise. The teachers, doctors and civil servants' working time is relatively fixed. Their work pressure is not so great. After their work, they have more free time to participate in physical exercise. Each time they spend 1 to $2 \mathrm{~h}$. At the same time, the income of the businesswomen also affects their consumption concept and the investment of physical exercise. The income level of the enterprise superintendents is higher in the female groups. They have higher income and higher social status. They have a stable economic foundation in physical exercise. Therefore, their consumption in physical exercise is higher. Furthermore, the doctors' income is above-average in the businesswoman groups. The amount of money they invest in physical activity is relatively larger. The teachers and civil servants' economic income is in the middle level. They can only meet the daily needs of physical exercise. They will not invest more money in physical exercise with high quality. The workers' participation in physical exercise is correlated to their income level. These 
businesswomen's income level is relatively lower. Most of the workers do not want to spend more money on physical exercise.

The businesswomen's willingness to have the second child is related to the nature of their work. The teachers and civil servants prefer to have the second child because they have relatively stable economic income while their working pressure is relatively small, followed by the workers whose wages are not very high but have a more positive attitude of two children. The doctors' working environment is relatively poor and they are often on night duty. Therefore, they are more willing to give birth to two children and relieve their pressure of work.

The businesswomen's choice of physical exercise programs.

Table 2 The physical exercise programs of the businesswomen from different fields

\begin{tabular}{|c|c|c|}
\hline Businesswomen & Physical exercise programs & Places \\
\hline Enterprise superintendents & $\begin{array}{l}\text { Swimming, tennis, bowling, } \\
\text { yoga, golf }\end{array}$ & $\begin{array}{l}\text { Residential fitness venues, } \\
\text { club, swimming pool, golf } \\
\text { course }\end{array}$ \\
\hline Civil servants & $\begin{array}{l}\text { Basketball, Football, } \\
\text { badminton, table tennis, } \\
\text { Wushu, Aerobics }\end{array}$ & Stadium, school court \\
\hline Teachers & $\begin{array}{l}\text { Fast walking football, } \\
\text { badminton, table tennis, yoga, } \\
\text { square dance, aerobics }\end{array}$ & $\begin{array}{l}\text { School court, ground track } \\
\text { field }\end{array}$ \\
\hline Doctors & $\begin{array}{l}\text { Basketball, mountaineering, } \\
\text { yoga, brisk, walking, sports } \\
\text { tourism, aerobics }\end{array}$ & Lighted court, gym \\
\hline Workers & $\begin{array}{l}\text { Badminton, running, square } \\
\text { dance }\end{array}$ & Leisure culture square \\
\hline
\end{tabular}

Table 2 shows the different ways of exercise and the places of exercise chosen by the businesswomen. Different businesswomen have different choices, which also reflects the distribution of the physical activities. The businesswomen with high income have higher requirement of the quality of the physical activity site. Most of the exercise programs chosen are tennis, bowling, yoga and so on. The choice of places are mostly residential fitness venues, clubs, etc. It can be seen that those in charge of the enterprises prefer higher spiritual quality. The teachers, doctors, civil servants and workers are pursuing simple physical fitness activities. Their requirements of the sites are not very high and their quality of physical exercise program investment is lower. At the same time, the professional characteristics and their choice of sports are related to each other. The characteristics of some occupations directly cause their interest and the choice of sports. For instance, the civil servants, teachers, doctors and workers mostly choose the sports they are interested. However, some people choice the sports, due to their indirect interest, such as the enterprise superintendents and female leaders. And the workers tend to choose the free parks and free public sports leisure places for their physical activities.

Table 3 The physical exercise programs of the businesswomen who have had the second child

\begin{tabular}{ccc}
\hline Businesswomen & Physical exercise programs & Places \\
\hline Enterprise superintendents & Swimming, yoga, walking & Fitness center, club, \\
Civil servants & Bwimming pool \\
Teachers & Brisk, table tennis, yoga & Gym, fitness path \\
Doctors & Yoga, brisk & School court, fitness path \\
Workers & Brisk, walking & Gym, fitness path \\
\hline
\end{tabular}

As can be seen from Table 3, the businesswomen who have had the second child prefer brisk, walking and yoga. And their exercise places are mainly the fitness path and the gym.

The influential factors of the businesswomen's physical exercise in the context of universal two-child policy 
Table 4 The businesswomen's physical exercise purposes (\%)

\begin{tabular}{cccccc}
\hline Businesswomen & $\begin{array}{c}\text { To strengthen } \\
\text { health }\end{array}$ & To relax & $\begin{array}{c}\text { To release } \\
\text { pressure }\end{array}$ & $\begin{array}{c}\text { To make } \\
\text { friends }\end{array}$ & Others \\
\hline $\begin{array}{c}\text { Enterprise } \\
\text { superintendents }\end{array}$ & 28 & 26 & 24 & 20 & 2 \\
Civil servants & 30 & 25 & 30 & 13 & 2 \\
Teachers & 35 & 30 & 12 & 22 & 1 \\
Doctors & 29 & 25 & 35 & 10 & 1 \\
Workers & 32 & 25 & 15 & 25 & 3 \\
\hline
\end{tabular}

Table 4 shows the businesswomen's purposes of physical exercise, mainly including to strengthen health, to relax, to release pressure and to make friends. No matter what their occupation is, the purpose of physical exercise is to strengthen health. For the civil servants and doctors, to release the pressure is one of their important goals. For the teachers and workers, to relax is also an important goal of their exercise.

Table 5 The influential factors that causing the businesswomen do not participate in physical exercise

\begin{tabular}{cll}
\hline Businesswomen & To take care of the first child & $\begin{array}{l}\text { To take care of the second } \\
\text { child }\end{array}$ \\
\hline Enterprise superintendents & (1)(3) & (1)(3)(7) \\
Civil servants & (1)(2)(3) & (1)(2)(3)(4)(5) \\
Teachers & (1)(3)(6) & (1)(3)(4)(5)(6) $(7)$ \\
Doctors & (1)(3)(6) & (1)(3)(5)(7)(6) \\
Workers & (1)(2)(3)(4) 6 & (1)(2)(3)(4) (5)(7) \\
\hline
\end{tabular}

(1)no spare time (2)the lack of the proper fitness places (3)no interest (4)not enough money (5)no supporting of the family members (6)the lack of basic exercise knowledge and skills (7)others

It can be seen from Table 4 that for the businesswomen who have only one child and who have had the second child, the influential factors that causing they do not participate in physical exercise are different. No free time is the most important factor, followed by the family members' supporting. For those who have had the second child, their inefficient money is also the key factor. The lack of basic knowledge and skills of activities also affect their participation. If a female has the need of physical exercise, faces the problem of two children's education and upbringing and lacks the family members' supporting and relevant professional training guidance, their physical and mental health will be seriously influenced.

\section{Conclusions and Suggestions}

Conclusions. Under the background of the universal two-child policy, those who plan to have the second child and participate in the physical exercises are relatively less. And their exercise items are single. They prefer to the fitness path near their house. The factors that promote their participation in physical exercises are physical fitness, entertainment, the release of pressure and making friends. The factors that cause them reject physical exercises are no free time, the lack of suitable places, not enough money, no supporting from the family members and the lack of activity knowledge and skills.

Suggestions. All levels of departments and relevant sectors should actively guide the businesswomen to participate in physical exercise, provide them corresponding conditions of exercises, improve the community residents' exercise facilities, so that they will meet the different needs of people with different occupations and participate in the physical exercises. The government and relevant departments should formulate the public and practical popularization with the help of TV. Under the background of the universal two-child policy, we should fully guarantee that the businesswomen will enjoy their reproductive autonomy, encourage them to have the second child and make them dare to have the second child. This will be for beneficial to the steady growth of China's population, the long-term demographic dividend and the fast development of the society. It will also play a positive role in effectively promoting the businesswomen's health, saving the social cost, 
ensuring the businesswomen's legal rights to give birth to a baby. All these are conducive to the long-term stability of the family, the society and our country.

\section{Acknowledgements}

National Innovation and Entrepreneurship Training and Planning Project for University Students.

\section{References}

[1] Pender NJ, Murdaugh CL, Parsons MA: Health promotion in nursing practice [M]. 5th ed. Upper Saddle River, NJ: Prentice Hall; 2005.

[2] Lin YH, Tsai EM, Chan TF, Chou FH, Lin YL: Health promoting lifestyles and related factors in pregnant women. Chang Gung medical journal 2009, 32(6):650-661.

[3] Lucas JA, Orshan SA, Cook F: Determinants of Health-Promoting Behavior Among Women Ages 65 and Above Living in the Community. Scholarly Inquiry for Nursing Pratice 2000, 14(1):77-100.

[4] Paulik E, Boka F, Kertesz A, Balogh S, Nagymajtenyi L: Determinants of health-promoting lifestyle behaviour in the rural areas of Hungary. Health promotion international 2010, 25(3):277-288.

[5] Pullen C, Walker SN, Fiandt K: Determinants of health-promoting lifestyle behaviors in rural older women. Family \& community health2001, 24(2):49-72.

[6] Wei CN, Harada K, Ueda K, Fukumoto K, Minamoto K, Ueda A: Assessment of health-promoting lifestyle profile in Japanese university students. Environmental health and preventive medicine 2011.

[7] Chen MY, Wang EK, Yang RJ, Liou YM: Adolescent health promotion scale: development and psychometric testing. Public Health Nurs 2003,20(2):104-110.

[8] Wang D, Ou CQ, Chen MY, Duan N: Health-promoting lifestyles of university students in mainland China. BMC public health 2009, 9:379.

[9] Sheng-long \& Da-jiang Lu, et al. Exploration in to the Four-in-one Sport Health Promotion Mode of Family-Community-Hospital-University [J] Journal of Beijing Sport University, 2015, 38 (11): 23-29.

[10] Zhi-ping Zhen \& Wen-hua Xing. Applied Research on Developing Health Promotion Strategy Combining with KAP in Fundamental Physical Education [J]. JOURNAL OF XI'AN INSTITUTE OF PHYSICAL EDUCATION, 2005, 22(4): 94-97.

[11] Pender,N.J.(1996).Health Promotion in Nursing Practice(3rded.).Norwalk. CT: Appleton Lange.

[12] Grubbs,L. \& Carter,J.(2002).The relationship of Perceived benefits and barriers to reported exercise behaviors in college undergraduates. Family \& Community Health, 25(2).

[13] Jie-ping Huang \& Qiu-jv Yin. Influence of Socioeconomic Status on Women's Health Risk [J]. Journal of Beijing Institute of Technology (Social Sciences Edition) , 2013, 10(5): 81-86. 